\title{
Actinobacillus suis and Actinobacillus equuli, emergent pathogens of septic embolic nephritis, a new challenge for the swine industry
}

\author{
Actinobacillus suis y Actinobacillus equuli, patógenos emergentes de nefritis embólica séptica, \\ un nuevo desafío para la industria porcina
}

\author{
CE Benaventea, IC Fuentealba ${ }^{a, b *}$ \\ aDepartment of Microbiology and Infectious Diseases, Faculty of Medicine, University of Calgary, Alberta, Canada. \\ bDepartment of Ecosystem and Public Health, Faculty of Veterinary Medicine, University of Calgary, Alberta, Canada.
}

\begin{abstract}
RESUMEN
Las lesiones renales son una causa importante de decomiso en los mataderos. Además de las posibles consecuencias en salud pública, el decomiso de órganos tiene un gran impacto económico en la industria de alimento animal. Recientemente, nefritis embólica séptica con lesiones semejantes a infecciones con Actinobacillus equuli en potrillos ha sido detectada en reproductoras y cerdos con peso de mercado. Actinobacillus equuli es fenotípica y genéticamente similar a Actinobacillus suis. Ambas son bacterias Gram-negativas difíciles de diagnosticar en exámenes de rutina. A. suis es un patógeno oportunista capaz de producir septicemia en cerdos, neumonía, poliartritis, nefritis embólica séptica, aborto y fetos momificados. Brotes de la enfermedad clínica parecieran ocurrir con más frecuencia en planteles de cerdos con estrictas medidas de bioseguridad. En cerdos adultos, las lesiones de piel pueden confundirse con erisipela porcina. A. suis y A. equuli son patógenos oportunistas emergentes en la industria porcina y ambos tienen potenciales consecuencias en salud pública, principalmente en aquellas personas que manipulan productos cárneos. El objetivo de esta publicación es presentar una revisión bibliográfica sobre el rol de A. suis y A. equuli en la patogénesis de nefritis en cerdos.
\end{abstract}

Key words: Actinobacillus suis, Actinobacillus equuli, nephritis, swine.

Palabras clave: Actinobacillus suis, Actinobacillus equuli, nefritis, cerdos.

\section{INTRODUCTION}

Recently, Actinobacillus equuli was associated with death of over 300 sows in a period of 2 months in a swine farm in Manitoba, Canada (Thompson et al 2010). The pattern of the inflammatory process corresponded to multifocal embolic nephritis. This condition is unique as the histopathological features resemble Actinobacillus equuli infection in foal. Common swine pathogens like Actinobacillus suis have been associated with polyserositis, pericarditis, pneumonia, arthritis, and very rarely with septicemia in adult pigs. Septicemia is important because of the potential of bacterial emboli that lodge in small capillaries and cause further lesions such as embolic nephritis or glomerulitis. Few reports of A. equuli infections in pigs have originated from North America in the last decade (Ramos-Vara et al 2008, Thompson et al 2010). Cases of embolic nephritis due to $A$. equuli infection have been diagnosed by several diagnostic laboratories in North America (personal communications).

\footnotetext{
Accepted: 10.11.2011.

* 3330 Hospital Dr NW, Calgary, AB 2TN, Canada; cfuentealba@ rossvet.edu.kn
}

Although the pathogenesis and etiology of renal diseases involve diverse modes and patterns of infection, all inflammatory lesions detected at the slaughter plants are classified under the broad category of "nephritis", often called "white-spotted kidneys" (Drolet et al 2002). Various pathogens have been associated with the presence of nephritis in condemned kidneys from swine. The purpose of this paper is to review the role of A. suis and A. equuli as emergent pathogens causing nephritis in swine.

\section{NEPHRITIS IN SWINE}

Renal disease which encompasses any deviation from normal renal structure or function is usually subclinical (Maxie 2007). Since by definition a subclinical condition is characterized by absence of clear clinical signs, disease in affected animals is not diagnosed and treatment is not implemented. Once the hogs reach the market weight, they are sent to the slaughterhouse and if lesions are detected by food inspectors the affected organs are condemned. The renal system is exposed to injurious agents by various routes, including: a) ascending infections, $b$ ) hematogenous, and c) exposure to preformed or locally metabolized substances that are excreted through the renal tubular epithelium. 


\section{CLASSIFICATION OF NEPHRITIS}

Renal diseases are complex and may primarily affect one of four subdivisions of the kidney: 1) renal blood vessels or its vascular supply, 2) glomeruli, 3) tubules, and 4) interstitium (Maxie 2007). However, due to the anatomic and functional interdependence of the components of the kidney it is common to find that damage to one structure almost always results in secondary damage to others (Alpers 2005). The main general types of nephritis are glomerulonephritis and tubulointerstitial diseases. Primary glomerular damage often occurs as a result of deposition of immune complexes, entrapment of bacterial emboli, or direct viral or bacterial infection of glomerular structures. Hematogenous lesions localized within blood vessels are classified as septic embolic nephritis, and non-septic necrosis with infarction caused by substances such as crystalline salts, and filtered toxins secreted into the filtrate (Golinski et al 1984, Newman et al 2007).

\section{CAUSES OF NEPHRITIS}

Bacteremia can produce embolic nephritis, also known as suppurative glomerulitis, in which bacteria lodge in random glomeruli and within interstitial capillaries forming multiple foci of inflammation (microabscesses) throughout the renal cortex. Pigs infected with Erysipelothrix rhusiopathiae (Wood and Henderson 2006), or A. equuli subsp. equuli (Thompson et al 2010), and foals infected with A. equuli subsp. equuli (Berthoud et al 2004) are specific examples of this condition. Grossly, multifocal random, raised, tan pinpoint foci are seen beneath the renal capsule and on the cut surface throughout the renal cortex. Microscopically, glomerular capillaries contain numerous bacterial colonies intermixed with necrotic debris that often obliterate the glomerulus (Newman et al 2007).

Bacterial infections with Escherichia coli, Corynebacterium sp., Staphylococcus sp., Streptococcus sp. (S. dysgalactiae subsp. equisimillis, S. suis, S. salivarius) have been isolated from kidneys of animals with interstitial nephritis (Martínez et al 2006). Viral infections also have been associated with this type of nephritis (Drolet $e t$ al 2002). Interstitial nephritis is traditionally associated with inflammatory cell infiltration composed of lymphocytes and plasma cells and surrounding the peritubular structures in the renal interstitium (veins, arteries, lymphatics and connective tissue) (Newman et al 2007). Interstitial nephritis, commonly known as "white-spotted kidneys", may be of infectious or non-infectious origin and according to the duration it is further classified as acute, subacute or chronic. Although this type of lesions can be caused by a variety of infectious agents, an association between interstitial nephritis and leptospirosis has been described (Baker et al 1989, Maxie 2007) but, this association is controversial (Jones et al 1987, Boqvist et al 2003). Leptospirosis is a zoonotic infectious disease caused by various serovars of
Leptospira interrogans, which affect a large number of wild and domestic species. The incidence of leptospirosis has decreased after the widespread use of vaccines; however, kidney condemnations are still common suggesting that additional organisms may be involved in the pathogenesis of interstitial nephritis (Drolet et al 2002). It has also been stated that vaccines do not prevent leptospira infection or provide a cure for chronically infected animals (Campagnolo et al 2000). It is clear that although numerous studies have attempted to elucidate which infectious agents are involved in interstitial nephritis in swine, the results varied and there is no convincing evidence that links a specific etiology for this condition (Martínez et al 2006).

In addition to bacteria, many emergent viral diseases have tropism for renal tissue (Drolet et al 2002, Imai et al 2006, Martinez et al 2006), including porcine reproductive and respiratory syndrome virus (PRRSV), porcine circovirus type 2 (PCV-2), porcine parvovirus (PPV), and porcine adenovirus (Nietfeld and Leslie-Steen 1993, Cooper et al 1997, Allan and Ellis 2000, Krakowka et al 2000, Drolet et al 2002, Segales et al 2005, Zimmerman et al 2006, Sarli et al 2008). Renal lesions in pigs inoculated with PRRS virus were characterized by moderate to marked interstitial nephritis, and mild to severe vascular changes (Cooper et al 1997). PCV-2 has been associated with tubulointerstitial nephritis (Sarli et al 2008), and a condition characterized by a systemic necrotizing vasculitis with marked cutaneous tropism (Langohr et al 2010). The latter syndrome, originally called porcine dermatitis and nephropathy syndrome, has been reported in several countries (Helie et al 1995) and is observed mainly in weaned and feeder pigs (Thibault et al 1998). There is evidence that PRRSV is also involved in the pathogenesis of this syndrome, since (a) its appearance coincided with the emergence of PRRSV, (b) characteristic lesions were seen in specific-pathogen free pigs infected with PRRSV (Cooper et al 1997), and (c) PRRSV antigens were detected by immunohistochemistry in macrophages surrounding affected vessels in skin and kidney in both acute and chronic spontaneous cases (Thibault et al 1998). Infection with PRRSV renders pig more susceptible to some bacterial and viral diseases, as an additive or synergistic effect, creating more severe disease than either agent alone (Zimmerman et al 2006, Xu et al 2010).

\section{CHARACTERISTICS OF ACTINOBACILLUS SUIS AND ACTINOBACILLUS EQUULI}

\section{ACTINOBACILLUS SUIS}

Actinobacillus suis has emerged as a new threat to swine health, particularly in high health status herds; and the occurrence of the disease in this group of pigs has been attributed to lack of herd immunity in these closed herds, but there is minimal information about the immunogenicity of A. suis (Yaeger 1996, MacInnes and 
Desrosiers 1999, Wilson and McOrist 2000, Lapointe et al 2001, Oliveira 2007). Actinobacillus suis is an early colonizer of the upper respiratory tract of swine (Oliveira et al 2007) and the nasopharynx and palatine tonsils are the main colonization sites (Ojha et al 2005). In order to learn more about the initial stages of A. suis disease, Ojha et al (2010) analyzed colonization-deficient mutants of $A$. suis which adhered to the epithelium (in vitro) in lower numbers than the wild type. In a study of 50 swine herds of Ontario, 78\% of them were diagnosed positive for $A$. pleuropneumoniae by apxIV PCR, and 94\% of the herds tested were found positive for both A. pleuropneumoniae and $A$. suis by apxII PCR, as evidenced by presence of these organisms in samples of tonsils and nostrils from weanling pigs. In another study, at least $16 \%$ and as many as $94 \%$ of the herds were A. suis positive (MacInnes et al 2008). Actinobacillus suis infection can take place via the aerosol route, close contact, or breaks in the skin (Sanford et al 1990, MacInnes and Bossé 2004). The systemic spread of A. suis involves septic emboli, which reach various organs including the kidney and produce septic embolic nephritis characterized by presence of bacterial microcolonies surrounded by areas of hemorrhage and necrosis (Odin 1994, Yaeger 1996, Oliveira 2007).

Species that belong to the genus Actinobacillus are mostly commensals or pathogens of animals, but have also been described as a potential opportunistic pathogens of humans, especially in people who are occupationally exposed to infected horses or pigs. For example, A. suis was isolated from a wound of a farmer after a pig bite (Escande et al 1996), and in a bone biopsy taken from an injured arm 3 months after a horse bite (Peel et al 1991). A. equuli was isolated from a butcher with septicemia due to a cut in his thumb three days earlier (Ashhurst-Smith et al 1998), and from a horse trainer with septicemia and multiple joint involvement (Vaz et al 2001).

Actinobacillus suis or A. suis-like bacteria have been isolated sporadically from other species, such as a Canada goose with conjunctivitis (Maddux et al 1987), an alpaca with endocarditis, embolic suppurative nephritis, pulmonary abscesses and interphalangeal arthritis (Hill and Johnstone 1992), lungs from a cat after undergoing an ovariohysterectomy (Daignault et al 1999), neonatal calves with septicemia (DeBey et al 1996), a buffalo with multiple abscesses (Sulochana et al 1985), a colt with ocular and nasal purulent discharge (Harbourne et al 1978), horses with abscesses, respiratory and genital infections (Carman and Hodges 1982, Carr et al 1997, Jeannotte et al 2002), and foals with septicemia (Nelson et al 1996). Mice can be infected with $A$. suis and subsequently develop pneumonia and bacteremia comparable to that seen in pigs, suggesting that mice may be used as a model for studying infection in swine (Ojha et al 2007). This organism is considered an opportunistic pathogen of both swine and horses (Pedersen 1977, Liven et al 1978, Jang et al 1987, Miniats et al 1989, Bada et al 1996, Ramos-Vara et al 2008), and it can cause fatal septicemia in young pigs (MacDonald et al 1976, Sanford et al 1990, MacInnes and Desrosiers 1999), pneumonia (Yaeger 1996), endocarditis (Ashford and Shirlaw 1962), polyarthritis (Wilson and McOrist 2000), and suppurative lesions in the kidney. Actinobacillus suis infection may also cause lesions resembling erysipelas in mature sows and gilts (Sanford and Miniats 1988, Miniats et al 1989, Wilson and McOrist 2000). A. suis can colonize the vagina of healthy sows and may cause abortion in gilts (Mauch and Bilkei 2004). Actinobacillus suis, characterized by biochemical properties, has been associated with infection of horses (Kim et al 1976, Harbourne et al 1978, Carman and Hodges 1982, Jang et al 1987), and septicemia in foals (Nelson et al 1996).

Actinobacillus suis has a wide geographical distribution. Cases have been reported from United States (Cutlip et al 1972, Maddux et al 1987, Nelson et al 1996), Canada (MacDonald et al 1976, Miniats et al 1989, Sanford et al 1990, Odin and Helie 1993), Great Britain (Harbourne et al 1978), New Zealand (Carman and Hodges 1982, Hill and Johnstone 1992), India (Sulochana et al 1985), Australia (Peel et al 1991, Wilson and McOrist, 2000), Hungary and Croatia (Mauch and Bilkei 2004).

Actinobacillus suis, a member of the family of Pasteurellaceae, genus Actinobacillus, is a small, gramnegative, oval to rod-shaped, capnophilic, non-mucoid, non-motile, nonspore producer, coccobacillary organism with short chains of bacillary and filamentous forms. India ink-crystal violet stain revealed that the organism is encapsulated (Cutlip et al 1972, MacDonald et al 1976, Harbourne et al 1978, DeBey et al 1996, Taylor 2006, Ojha et al 2007). Actinobacillus suis is catalase and oxidase positive, can grow on Mac Conkey's agar, and is nitrate and urease positive but indole negative. This microorganism is hemolytic when grown upon 5\% sheep blood agar and hydrolyses esculin. Mannitol is not fermented by $A$. suis (Mair et al 1974, Sulochana et al 1985, DeBey et al 1996, Yaeger 1996, Daignault et al 1999, Rycroft and Garside 2000, Mauch and Bilkei 2004, Woldehiwet 2004). Although iron is plentiful in animal hosts, it is not readily available to pathogens due to iron-withholding properties of transferrin and lactoferrin. A. suis is an iron-requiring pathogen that must be capable of acquiring iron from its host despite the iron-restricted environment. Pathogenic members of Pasteurellaceae can obtain iron directly from the host proteins, most notably from transferrins (Tfs), by means of siderophore-independent, receptor-mediated mechanisms. This mechanism involves two surface receptor proteins referred to as Tf-binding proteins $\mathrm{A}$ and B (Bahrami et al 2003). Actinobacillus suis also has the ability to acquire iron from hemoglobins for growth and involves a single-component receptor that is up-regulated in response to iron restriction (Bahrami and Niven 2005). Actinobacillus suis has been described to secrete metalloproteases in vitro and these proteins displayed proteolytic activity. Metalloproteases degrade pig and bovine $\operatorname{IgG}$ 
and they may have a role in diseases caused by A. suis (Negrete-Abascal et al 2004). Microbial proteases exert direct pathological effects by destroying host tissues and potentiate inflammatory processes.

Actinobacillus suis is not easy to routinely diagnose (Minton 2008), as it can be isolated along with other bacteria, and may be present in chronic cases (MacDonald 1976 , Yaeger 1996). Moreover, isolation A. suis from clinical samples may be influenced by treatment with antibiotics, or poor handling of samples prior to submission to the diagnostic laboratory. In this case, polymerase chain reaction (PCR) can be used as an alternative tool to help with the final diagnosis of A. suis infection (Oliveira 2007).

The pathogenicity of disease caused by A. suis is not well understood. Potential virulence factors that have been reported for this microorganism include production of toxins, capsule expression, urease, and resistance to complement-mediated killing. Actinobacillus suis has genes that encodes pore-forming protein toxins belonging to the RTX (repeats in the structural toxin) family and are very similar to ApxI and ApxII of Actinobacillus pleuropneumoniae (Burrows and Lo 1992, Kamp et al 1994, Van Ostaaijen et al 1997, Frey and Kuhnert 2002), resulting in the development of similar lesions caused by these two microorganisms (Fenwick et al 1996, Jeannotte et al 2002). It is likely that two RTX toxins (ApxI and ApxII), capsular polysaccharides (CPSs) $(\mathrm{K})$ and lipopolysaccharides (LPSs) (O), an iron-regulated outer-membrane proteins, and resistance to complement-mediated killing contribute to virulence (Slavic et al 2000a, Slavic et al $2000^{\mathrm{b}}$, Bahrami et al 2003, Kuhnert et al 2003a , Bahrami and Niven 2005, Ojha et al 2007, Oliveira 2007, RamosVara et al 2008). RTX toxins are produced by a broad range of pathogenic Gram-negative bacteria. The toxins exhibit both a cytotoxic and often a hemolytic activity in vitro and few RTX toxins have cytotoxic activity only against cells of specific hosts and/or cell-type, suggesting that they may play a role in host specificity of certain pathogens (Frey and Kuhnert 2002). For example, A. suis and $A$. equuli have host specific specificity toxins, whereby A. suis has the apxICA and apxIICA genes, (Kuhnert et al 2003 ${ }^{\mathrm{a}}$, Kuhnert et al 2003 ${ }^{\mathrm{b}}$ ) that are not present in $A$. equuli (Ramos-Vara et al 2008).

The cell surface CPSs and LPSs of Gram-negative bacteria also play key roles in bacteria-host interactions. Monteiro et al (2000) described the presence of $(1 \rightarrow 6)-\beta$-D-glucan in the LPSs and CPSs of $A$. suis, and the strains expressing that homopolymer as LPS-O-chains and CPSs were designed serotype $\mathrm{O} 1 / \mathrm{K} 1$. The presence of $(1 \rightarrow 6)-\beta$-D-glucan is also found in common environmental fungal organisms and yeast, and some pigs may have low levels of antibody resulting in false positive results for $A$. suis by using LPS/CPS based in enzyme-linked immunosorbent assay (ELISA). A study was also done with the O-antigen polysaccharide (PS) chemical structure of an $\mathrm{O} 2$ serogroup strain of $A$. suis, which is associated with severely diseased animals and produce a more complex O-chain PS. The capsule PS (K2) of these strains contains sialic acic, a residue that has been associated with many immunological events (Rullo et al 2006). A cell surface antigen-typing was devised for $A$. suis and used to examine the prevalence of different lipopolysaccaride $(\mathrm{O})$ types in healthy and diseased pigs and the authors concluded that O2/K3-reactive strains may be more virulent than O1/K1 strains (Slavic et al 2000a , Slavic et al 2000 ). Although $\mathrm{O} 1 / \mathrm{K} 1$ and $\mathrm{O} 1 / \mathrm{K} 2$ strains were isolated from clinically "healthy" pigs (asymptomatic animals), they both have a potential to cause disease. However, differences in the histopathologic changes and in the ability to spread peritonitis between $A$. suis serotypes $\mathrm{O} 1 / \mathrm{K} 1, \mathrm{O} 1 / \mathrm{K} 2$, and $\mathrm{O} 2 / \mathrm{K} 2$ have been reported (Slavic et al 2000a).

The rapid spread of the disease between two isolated herds suggested that $A$. suis can be readily transmitted by humans and/or by carrier pigs (Miniats et al 1989). The ability of A. suis to survive in the environment has not been fully described but there is evidence that the organism can persist in an infected herd for at least 18 months (Miniats et al (1989). A. suis is killed within 15 minutes at a temperature of $60^{\circ} \mathrm{C}$, is sensitive to most disinfectants, and will die out within a few days in clinical specimens (Oliveira 2007).

Despite the fact that $A$. suis is sensitive to a wide range of antibiotics (procaine penicillin G, trimethoprim sulfadoxine, oxytetracycline $\mathrm{HCl}$ (Miniats et al 1989), the rapid onset of the disease makes effective treatment difficult. Sanford et al (1990) reported that in their study all $28 \mathrm{~A}$. suis isolates were susceptible to ampicillin, carbenicillin, gentamicin, kanamycin, penicillin $\mathrm{G}$, polymyxin $\mathrm{B}$, and trimethoprim-sulfamethoxazole; one isolate was resistant to tetracycline and sulfisoxazole, another isolate was resistant to tetracycline only. On the other hand, Wilson and McOrist (2000) reported that all A. suis isolates were susceptible in vitro to a lincomycin-spectinomycin combination and resistant to tetracyclines, macrolides and penicillins, while two were resistant to apramycin and trimethoprim-sulphamethoxazole. Oliveira (2007) observed that A. suis isolates sharing similar genomic fingerprints may have completely different susceptibility profiles, suggesting that antibiotic resistance genes may be carried in plasmids, and strains with similar genetic makeup may carry different plasmids.

Clinical signs and lesions caused by A. suis are usually non-specific, and a list of differential diagnoses associated with other pathogens that can cause septicemia is necessary for the development of effective control strategies. Bacterial pathogens that can cause systemic infection in swine include members of the family Pasteurellaceae as Haemophilus parasuis (cause fibrinous pleuritis, pericarditis and polyserositis) and A. pleuropneumoniae (common cause of pneumonia), and Erysipelothrix rhusiopathiae (typical lesions include endocarditis, arthritis and skin lesions) (Robinson and Maxie 1993) causing 
significant production losses. A. suis can be isolated from clinical samples or it can be detected by PCR (Oliveira 2007). The most promising technique for identification of Actinobacillus spp. and other pathogens is PCR tests based on species specific genetic elements including virulence genes (Christensen and Bisgaard 2004).

Vaccination and serodiagnostic testing are complicated by the presence of multiple serotypes, and cross-reactive antigens (Rosendal and Mittal 1985, Fenwick et al 1996, MacInnes and Desrosiers 1999, Lapointe et al 2001, Oliveira 2007). Currently, no sero-diagnostic tests or vaccines are commercially available to help controlling $A$. suis infections (Oliveira et al 2007). Autogenous vaccines are sometimes used in herds with clinical problems, but their efficacy has not been critically evaluated. Serologic profile could be used to determine the duration of passive immunity in a specific herd in order to help implementing the best vaccination strategy. The use of autogenous $A$. suis vaccine increased the specific humoral immunity in gilts (Lapointe et al 2001). Oliveira et al (2007) reported that $A$. suis affecting North American swine herds are highly clonal and this information may be important for the selection of vaccine strains. Some commercial A. pleuropneumoniae vaccines, containing A $p x$ toxoids, might provide some cross protection. Furthermore, Lillie et al (2006) characterized porcine plasma lectins with bacteria-binding functions against A. suis and Haemophilus parasuis which may play a role on innate resistance to bacterial pathogens in pigs.

Review of the literature seems to indicate that porcine actinobacillosis, which previously was considered to be a disease of minor importance, present a health hazard to naïve, susceptible swine population. This seems to be particularly important in farms using modern management practices such as segregated weaning, closed breeding and in minimal disease herds.

\section{ACTINOBACILLUS EQUULI}

Actinobacillus equuli is phenotypically and phylogenetically related to A. suis (Bisgaard et al 1984) and some strains have been previously misidentified or at least misnamed as equine "A. suis" (Kuhnert et al 2003b). For many years the uncertain taxonomy have represented a diagnostic problem and prevented progress on studies of virulence and epidemiology of these organisms (Ross et al 1972). Actinobacillus equuli is a small, non-motile, gram-negative rod and differs from A. suis by producing acid from mannitol, and not hydrolyzing esculin (Sanford et al 1990). Early attempts to distinguish between isolates from healthy horses and clinically ill cases using ribotyping and biochemical fingerprinting were not useful (Sternberg and Brandstrom 1999) but in subsequent studies A. equuli was reclassified in two subspecies: A. equuli subsp. equuli and $A$. equuli subsp. haemolyticus, showing different disease pattern and epidemiology. The main features used for differentiation of the two subspecies are haemolysis and the CAMP reaction (Christie et al 1944); A. equuli subsp. equuli is non-haemolytic and CAMP-negative. Haemolysis is observed in infections due to A. equuli subsp. haemolyticus and A. suis (Christensen et al 2002). RTX toxin activity has been found in strains of $A$. equuli subsp. haemolyticus and the Aqx haemolysin has been shown to be toxic for horse lymphocytes (Berthoud et al 2002). A toxin gene analysis revealed that all A. equuli subsp. haemolyticus strains specifically contained $a q x$ gene which confers the hemolytic phenotype of this subspecies, while A. suis strains harbored the genes apxI and apxII. Moreover, A. equuli subsp. equuli contained no aqx nor any of the other RTX genes tested. The specificity of $a q x$ for the hemolytic equine A. equuli and apxI and apxII for the porcine $A$. suis indicates a role of these RTX toxins in host species predilection of the two closely related species of bacterial pathogens and allows polymerase chain reaction (PCR) based diagnostic differentiation of the two (Kuhnert et al 2003a). The Aqx toxin was associated with pulmonary hemorrhage and endothelial damage in an adult horse (Pusterla et al 2008).

The natural host of A. equuli is the horse and the organism is found in the oral cavity and alimentary tract of horses, which commonly leads to the exposure of their immune system to this bacterial species and its antigens. Adult horses had antibodies directed to Aqx toxin of A. equuli (Berthoud et al 2004, Holyoak et al 2007). Actinobacillus equuli has been associated with several diseases in foals and adult horses, and the most important condition is fatal septicemia in neonatal foals which is thought to be associated with a failure of passive transfer of immunoglobulins via the colostrum. Interestingly, only A. equuli subsp. equuli, a non-hemolytic subspecies is associated with "sleepy foal disease", a clinical condition characterized by acute septicemia of foals with purulent nephritis which eventually becomes chronic in the form of "joint ill", a polyarthritis (Kuhnert et al 2003a). Infections in adult horses due to $A$. equuli are less common and generally more localized as it is described in cases of arthritis, endocarditis (Aalbaek et al 2007), abortion (Webb et al 1976), septicemia, nephritis, pneumonia (Carr et al 1997, Pusterla et al 2008), and orchitis (Patterson-Kane et al 2001). A few cases of acute and chronic peritonitis caused by A. equuli infection have also been documented in adult horses (Gay and Lording 1980, Golland et al 1994, Patterson-Kane et al 2001). The pathogenesis of peritoneal infection caused by $A$. equuli is unclear. In addition to septicemia resulting in polyserositis, and or peritonitis, other routes of infection are possible. Carriage of A. equuli by Strongylus sp. larvae from the intestinal tract may play a role in peritoneal invasion (Gay and Lording 1980, Golland et al 1994). The feasibility of this route of infection is supported by the fact that $A$. equuli has been isolated from verminous aneurysms of the cranial mesenteric arteries caused by Strongylus vulgaris larvae (Golland et al 1994). Mesenteric and cecocolic verminous arteritis lesions were observed in one horse with chronic 
A. equuli peritonitis (Gay and Lording 1980). However, A. equuli peritonitis is a rare diagnosis in adult horses but because appropriate antimicrobial treatment in small numbers of horses with acute $A$. equuli peritonitis has resulted in clinical improvement and a return to original activity, diagnosis Patterson-Kane et al (2001) suggested that pathologists and clinicians examining smears of abdominal fluid from equine colic cases should be aware of this etiologic agent.

Reports of $A$. equuli infection in pigs are uncommon and come mostly from European countries (Bell 1973, Ramos-Vara et al 2008). Only few reports have been published during the last decades in North America: A. equuli has been associated with vegetative endocarditis in pigs (Jones and Simmons 1971), isolated from an aborted porcine fetus (Werdin et al 1976), reported as a cause of metritis, valvular endocarditis with secondary septicemia in a pregnant gilt (Ramos-Vara et al 2008), and recently, A. equuli subsp. equuli was isolated from a sow herd affected with peracute clinical disease progression and abnormally high mortality of 300 sows from an initial population of 3000 females and 1 to 4 day-old piglets (Thompson et al 2010).

The most likely method of spread of the genus Actinobacillus between horses and pigs seems to be previous contact between both species in the farm (Windsor 1973, Werdin 1976, Harbourne et al 1978, Nelson et al 1996), but a case of $A$. equuli infection in swine was reported from a farm in which pigs were raised in an environment without contact with horses (Ramos-Vara et al 2008). Cases of A. equuli infection were reported in a farm with excellent biosecurity standards, but it was also reported that although the sows had no direct contact with horses several barn employees were known to be in contact with horses (Thompson et al 2010).

Septicemic actinobacillosis in pigs is usually attributed to $A$. suis (Odin 1994) but $A$. equuli can produce septicemia in piglets and sows, with similar lesions in kidneys, joints and endocardium (Taylor 2006, Ramos-Vara et al 2008). To date, A. equuli subsp. haemolyticus has only been isolated from horses, whereas $A$. equuli subsp. equuli has been isolated from pigs and horses. Ramos-Vara et al (2008) utilized a molecular approach to detect and identify the bacteria in the affected pig tissues. Analysis of the amplified nucleotide sequences revealed $100 \%$ homology with two A. equuli isolates (GenBank AY634640 and AY465359) and PCR typing of the RTX genes ruled out A. suis and A. equuli subsp. haemolyticus. Moreover, Thompson et al (2010) identified A. equuli subsp. equuli from the lung and kidney tissue of sows using a bacterial identification system and the $16 \mathrm{~S}$ ribosomal RNA gene sequencing.

In recent cases of $A$. equuli subsp. equuli infection in sows antibiotic susceptibility tests indicated that the bacterium was sensitive to tetracycline, neomycin, trimethoprin, ceftiofur, spectinomycin, and ampicillin (Thompson et al 2010). An autogenous killed vaccine was developed and within 6 weeks following the onset of the clinical outbreak, the entire sow herd was vaccinated. In order to prevent clinical disease in replacement animals, gilts were vaccinated twice prior to entry into the herd (Thompson et al 2010).

\section{CONCLUDING REMARKS}

Although a differential diagnosis of porcine actinobacillosis as the result of A. equuli is not commonly considered in swine, veterinarians should be aware of the importance of this pathogen in cases of septicemia. The recent report of an outbreak of $A$. equuli infection in swine (Thompson et al 2010), the isolation of the organism in pure culture from species other than equine (Moyaert et al 2007), and the unpublished observations from diagnostic laboratories support the interpretation that this is either an emerging pathogen, or has been previously under-diagnosed. Bacterial endocarditis in pigs is usually linked to Streptococcus spp. and Erysipelothrix rhusiopathiae infections (Robinson and Maxie 1993), but valvular endocarditis has been reported in natural and experimental $A$. equuli infections of piglets and in natural infections in foals. Any septicemic condition has the potential to cause embolism in small blood vessels, and cause endothelial damage including endocarditis. The pathogenesis of thromboembolism starts with primary infection, followed by secondary bacteremia, bacterial colonization of multiple organs and culminating with thromboembolism (Odin 1994). Thus, it is important to recognize that embolic nephritis is an entity with many possible causes, including A. suis and A.equuli. Both pathogens are associated with infection in humans, particularly people involved in activities that puts them in close contact with horses and pigs, or individuals that handle tissues from these animals. Isolation and identification of the etiologic agent are required to achieve an accurate diagnosis and to implement adequate therapeutic and management strategies.

\section{SUMMARY}

Kidney lesions are an important cause of tissue condemnation in slaughterhouses. In addition to the potential public health implications, organ condemnations have a significant economic impact on the food animal industry. The condition classified broadly as "nephritis" is one of the main causes of tissue condemnation. Embolic nephritis resembling Actinobacillus equuli infection in foals has been recently detected in sows and market hogs. Actinobacillus suis is phenotypically and phylogenetically closely related to A. equuli. Both are Gram-negative bacteria, not easy to detect in routine exams. A. suis is an opportunistic pathogen that can produce fatal septicaemia in pigs, pneumonia, polyarthritis, septic embolic nephritis, abortion and mummified foetuses. Outbreaks of clinical disease appear to occur more frequently in high-health-status herds. In adult pigs the skin lesions may be confused with porcine erysipelas. $A$. suis and A. equuli are emerging opportunistic pathogens in the porcine industry and both have potential public health consequences to people that handles meat products. The objective of this paper is to present a literature review regarding the role of $A$. suis and $A$. equuli in the pathogenesis of nephritis in swine. 


\section{REFERENCES}

Aalbaek B, S Ostergaard, R Buhl, HE Jensen, H Christensen, M Bisgaard. 2007. Actinobacillus equuli subs. equuli associated with equine valvular endocarditis. APMIS 115, 1437-1442.

Allan GM, JA Ellis. 2000. Porcine circoviruses: a review. J Vet Diagn Invest $12,3-14$

Alpers CE. 2005. The kidney. In: Kumar AK, Fausto N (eds). Robbins and Cotran. Pathologic Basis of Disease. $7^{\text {th }}$ ed. Elsevier, Philadelphia, USA, Pp 955-960.

Ashford WA, JF Shirlaw. 1962. A case of verrucous endocarditis in piglet caused by an organism of the Actinobacillus genus. Vet Rec 74, 1417-1418

Ashhurst-Smith C, R Norton, W Thoreau, MM Peel. 1998. Actinobacillus equuli septicemia: an unusual zoonotic infection. J Clin Microbiol $36,2789-2790$

Bada R, KR Mittal, R Higgins. 1996. Biochemical and antigenic relationships between porcine and equine isolates of Actinobacillus suis. Vet Microbiol 51, 393-396.

Bahrami F, A Ekins, DF Niven. 2003. Iron acquisition by Actinobacillus suis: identification and characterization of transferring receptor proteins and encoding genes. Vet Microbiol 94, 79-92.

Bahrami F, DF Niven. 2005. Iron acquisition by Actinobacillus suis; identification and characterization of a single-component haemoglobin receptor and encoding gene. Microb Pathog 39, 45-51.

Baker TF, SA McEwen, JF Prescott, AH Meek. 1989. The prevalence of leptospirosis and its association with multifocal interstitial nephritis in swine at slaughter. Can J Vet Res 53, 290-294.

Bell JC. 1973. Actinobacillus equuli infection in pigs. Vet Rec 92, 543-544.

Berthoud H, J Frey, P Kuhnert. 2002. Characterization of Aqx and its operon: the hemolytic RTX determinant of Actinobacillus equuli. Vet Microbiol 87, 159-174.

Berthoud H, J Frey, S, Sternberg, R Straub, P Kuhnert. 2004. Antibodies to Aqx toxin of Actinobacillus equuli in horses and foals. Vet Rec 155, 231-233.

Bisgaard M, K Piechulla, YT Ying, W Frederiksen, W Mannheim. 1984. Prevalence of organisms described as Actinobacillus suis or haemolytic Actinobacillus equuli in the oral cavity of horses. Comparative investigations of strains obtained and porcine strains of A. suis sensu stricto. Acta Pathol Microbiol Immunol Scand Sect B 92, 291-298.

Boqvist S, JM Montgomery, M Hurst, HT Thu, EO Engvall, A Gunnarsson, U Magnusson. 2003. Leptospira in slaughtered fattening pigs in southern Vietnam: Presence of the bacteria in the kidneys and association with morphological findings. Vet Microbiol 93, 361-368.

Burrows LL, LO RY. 1992. Molecular characterization of an RTX toxin determinant from Actinobacillus suis. Infect Immun 60, 2166-2173.

Campagnolo ER, MC Warwick, HL Jr Marx, RP Cowart, HD Jr Donnel, MD Bajani, SL Bragg, JE Esteban, DP Alt, JW Tappero, CA Bolin, DA Ashford. 2000. Analysis of the 1998 outbreak of leptospirosis in Missouri in humans exposed to infected swine. $J$ Am Vet Med Assoc 216, 676-682.

Carman MG, RT Hodges. 1982. Actinobacillus suis infection of horses. New Zeal Vet J 30, 82-84.

Carr EA, GP Carlson, WD Wilson, DH Read. 1997. Acute hemorrhagic pulmonary infarction and necrotizing pneumonia in horses: 21 cases (1967-1993). J Am Vet Med Assoc 210, 1774-1778.

Christensen H, M Bisgaard, JE Olsen. 2002. Reclassification of equine isolates previously reported as Actinobacillus equuli, variants of $A$. equuli, Actinobacillus suis or Bisgaard taxon 11 and proposal of $A$. equuli subsp. equuli subsp. nov. and A. equuli subsp. haemolyticus subsp. nov. Int J Syst Evol Microbiol 52, 1569-1576.

Christensen H, M Bisgaard. 2004. Revised definition of Actinobacillus sensu stricto isolated from animals. A review with special emphasis on diagnosis. Vet Microbiol 99, 13-30.
Christie R, NE Atkins, E Munch-Petersen. 1944. A note on a lytic phenomenon shown by group B Streptococci. Aust J Exp Biol Med Sci 2, 197-200.

Cooper VL, RA Hesse, AR Doster. 1997. Renal lesions associated with experimental porcine reproductive and respiratory syndrome virus (PRRSV) infection. J Vet Diagn Invest 9, 198-201.

Cutlip RC, WC Amtower, MR Zinober. 1972. Septic embolic actinobacillosis of swine: A case report and laboratory reproduction of the disease. Am J Vet Res 33, 1621-1626.

Daignault D, L Chouinard, K Moller, P Ahrens, S Messier, R Higgins. 1999. Isolation of Actinobacillus suis from a cat's lung. Can Vet $J$ 40, 52-53.

DeBey BM, PC Blanchard, RL Walker. 1996. Actinobacillus suis-like organisms associated with septicemia in neonatal calves. $J$ Vet Diagn Invest 8, 248-250.

Drolet R, S D'Allaire, R Larochelle, R Magar, M Ribotta, R Higgins. 2002. Infectious agents identified in pigs with multifocal interstitial nephritis at slaughter. Vet Rec 150, 139-143.

Escande F, A Bailly, S Bone, J Lemozy. 1996. Actinobacillus suis infection after a pig bite. The Lancet 348,888 .

Fenwick B, M Rider, MMJ Chengappa, J Montaraz. 1996. Cross protective immunity between Actinobacillus suis and Actinobacillus pleuropneumoniae. Proceedings $14^{\text {th }}$ of the Congress International Pig Veterinary Society, Bologna, Italy.

Frey J, P Kuhnert. 2002. RTX toxins in Pasteurellaceae. Int J Med Microbiol 292, 149-158.

Gay CC, PM Lording. 1980. Peritonitis in horses associated with Actinobacillus equuli. Aust Vet J 56, 296-300.

Golinski P, K Hult, J Grabarkiewicz-Szczesna, J Chelkowski, P Kneblewski, K Szebiotko. 1984. Mycotoxic porcine nephropathy and spontaneous occurrence of Ochratoxin A residues in kidneys and blood of Polish swine. Appl Environm Microbiol 47, 1210-1212.

Golland LC, DR Hodgson, JL Hodgson, MA Brownlow, DR Hutchins, RJ Rawlinson, MC Collins, SA Mc Clintock, AL Raisis. 1994. Peritonitis associated with Actinobacillus equuli in horses: 15 cases (1982-1992). J Am Vet Med Assoc 205, 340-343.

Harbourne JF, NS Mair, SG Keighley. 1978. Isolation of Actinobacillus suis from a colt. Br Vet $J$ 134, 122-127.

Helie P, R Drolet, MC Germain, A Bourgault. 1995. Systemic necrotizing vasculitis and glomerulonephritis in grower pigs in southwestern Quebec. Can Vet J 36, 150-154

Hill FI, AC Johnstone. 1992. Actinobacillosis in an alpaca (Lama pacos). New Zeal Vet J 40, 28-30.

Holyoak GR, CM Smith, R Boyette, M Montelongo, JH Wray, S Ayalew, VE Duggan, AW Confer. 2007. Serum antibodies in mares and foals to Actinobacillus equuli whole cells, outer membrane proteins, and Aqx toxin. Vet Immunol Immunopath 118, 310-316.

Imai DM, J Cornish, R Nordhausen. 2006. Renal tubular necrosis and interstitial hemorrhage ("turkey-egg kidney") in a circovirus-infected Yorkshire cross pig. J Vet Diagn Invest 18, 496-499.

Jang SS, EL Biberstein, DC Hirsh. 1987. Actinobacillus suis-like organisms in horses. Am J Vet Res 48, 1036-1038.

Jeannotte ME, D Slavic, J Frey, P Kuhnert, JI MacInnes. 2002. Analysis of non-porcine isolates of Actinobacillus suis. Vet Microbiol 85, 83-93.

Jones JE, JR Simmons. 1971. Endocarditis in a pig caused by Actinobacillus equuli: A field and an experimental case. Br Vet J 127, 25-29.

Jones RT, BD Millar, RJ Chappel, B Adler. 1987. Macroscopic kidney lesions in slaughtered pigs are an inadequate indicator of current leptospiral infection. Aust Vet J 64, 258-259.

Kamp EM, TM Vermeulen, MA Smits, J Haagsma. 1994. Production of Apx toxins by field strains of Actinobacillus pleuropneumoniae and Actinobacillus suis. Infect Immun 62, 4063-4065.

Kim BH, JE Phillips, JG Atherton. 1976. Actinobacillus suis in the horse. Vet Rec 98, 239.

Krakowka S, JA Ellis, B Meehan, S Kennedy, F McNeilly, G Allan. 2000. Viral wasting syndrome of swine: Experimental reproduction of postweaning multisystemic wasting syndrome in gnotobiotic 
swine by confection with porcine circovirus type 2 and porcine parvovirus. Vet Path 37, 254-263.

Kuhnert P, H Berthoud, H Christensen, M Bisgaard, J Frey. 2003a. Phylogenetic relationship of equine Actinobacillus species and distribution of RTX toxin genes among clusters. Vet Res 34, 353-359.

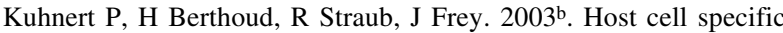
activity of RTX toxins from haemolytic Actinobacillus equuli and Actinobacillus suis. Vet Microbiol 92, 161-167.

Langohr IM, GW Stevenson, EA Nelson, SD Lenz, H HogenEsch, H Wei, RM Pogranichniy. 2010. Vascular lesions in pigs experimentally infected with porcine circovirus type 2 serogroup b. Vet Pathol 47, 140-147.

Lapointe L, S D'Allaire, S Lacouture, M Gottschalk. 2001. Serologic profile of a cohort of pigs and antibody response to an autogenous vaccine for Actinobacillus suis. Vet Res 32, 175-183.

Lillie BN, JD Hammermueller, JJ MacInnes, M Jacques, MA Hayes.2006. Porcine mannan-binding lectin A binds to Actinobacillus suis and Haemophilus parasuis. Develop Comp Immun 30, 954-965.

Liven E, HJ Larsen, B Lium. 1978. Infection with Actinobacillus suis in pigs. Acta Vet Scand 19, 313-315.

MacDonald DW, MP Hewitt, GS Wilton, S Rawluk, L Childs. 1976. Actinobacillus suis infections in Alberta swine, 1973-75: Pathology and bacteriology. Can Vet J 17, 251-254.

MacInnes JI, R Desrosiers. 1999. Agents of the "suis-ide diseases" of swine: Actinobacillus suis, Haemophilus parasuis, and Streptococcus suis. Can J Vet Res 63, 83-89.

MacInnes JI, JT Bosse. 2004. Actinobacillus. In: Gyles CL, Prescott JF, Songer JG, Thoen CO (eds). Pathogenesis of bacterial infections in animals. $3^{\text {rd }}$ ed. Blackwell Publishing, Ames, Iowa, USA, Pp 225-241.

MacInnes JI, M Gottschalk, AG Lone, DS Metcalf, S Ojha, T Rosendal, SB Watson, RM Friendship. 2008. Prevalence of Actinobacillus pleuropneumoniae, Actinobacillus suis, Haemophilus parasuis, Pasteurella multocida, and Streptococcus suis in representative Ontario swine herds. Can J Vet Res 72, 242-248.

Maddux RL, MM Chengappa, BG McLaughlin. 1987. Isolation of Actinobacillus suis from a Canada goose (Branta Canadensis). J Wildlife Dis 23, 483-484.

Mair NS, CJ Randall, GW Thomas, JF Harbourne, CT McCrea, KP Cowl. 1974. Actinobacillus suis infection in pigs: a report of four outbreaks and two sporadic cases. J Comp Pathol 84, 113-119.

Martínez J, J Segales, G Aduriz, R Atxaerandio, P Jaro, J Ortega, B Peris, JM Corpa. 2006. Pathological and etiological studies of multifocal interstitial nephritis in wasted pigs at slaughter. Res Vet Sci 81, 92-98.

Mauch C, G Bilkei. 2004. Actinobacillus suis, a potential cause of abortion in gilts and low parity sows. Vet $J 168,186-187$.

Maxie MG. 2007. The urinary system. In: Maxie MG (ed). Pathology of Domestic Animals. $5^{\text {th }}$ ed. Elsevier Saunders, Philadelphia, USA, Pp 452-522.

Miniats OP, MT Spinato, SE Sanford. 1989. Actinobacillus suis septicemia in mature swine: two outbreaks resembling erysipelas. Can Vet J 30, 943-947.

Minton B. 2008. Actinobacillus suis poses uncertain risk. National Hog Farmer 53, 34.

Monteiro MA, D Slavic, F St.Michael, JR Brisson, JI MacInnes, MB Perry. 2000. The first description of a $(1 \rightarrow 6)$-beta-D-glucan in prokaryotes: $(1 \rightarrow 6)$-beta-D-glucan is a common component of Actinobacillus suis and is the basis for a serotyping system. Carbohydr Res 329, 121-130.

Moyaert H, A Decostere, M Baele, K Hermans, P Tavernier, K Chiers, F Haesebrouck. 2007. An unusual Actinobacillus equuli strain isolated from a rabbit with Tyzzer's disease. Vet Microbiol 124, 184-186.

Negrete-Abascal E, SV Pacheco, GL Paniagua, AP Mendez, JI Caballero, VM Marquez, VR Tenorio. 2004. Metalloproteases secreted by Actinobacillus suis. Curr Microbiol 49, 55-58.

Nelson KM, BJ Darien, DM Konkle, FA Hartmann. 1996. Actinobacillus suis septicemia in two foals. Vet Rec 138, 39-40.
Newman SJ, AW Confer, RJ Panciera. 2007. Urinary system. In: McGavin (ed). Pathologic basis of veterinary disease. $4^{\text {th }}$ ed. Mosby Elsevier, Philadelphia, USA. Pp 613-680.

Nietfeld JC, P Leslie-Steen. 1993. Interstitial nephritis in pigs with adenovirus infection. J Vet Diagn Invest 5, 269-279.

Odin M, P Helie. 1993. Actinobacillus suis in swine in southwestern Quebec. Can Vet J 34, 634

Odin M. 1994. Les infections à Actinobacillus suis au Québec: une étude rétrospective de 22 cas. Le Médecin Vétérinaire du Québec 24, 61-65.

Ojha S, M Sirois, JI MacInnes. 2005. Identification of Actinobacillus suis genes essential for the colonization of the upper respiratory tract of swine. Infect Immun 73, 7023-7039.

Ojha S, MA Hayes, PV Turner, JI MacInnes. 2007. An experimental model of Actinobacillus suis infection in mice. Comp Med 57, 340-348.

Ojha S, S Lacouture, M Gottschalk, JJ MacInnes. 2010. Characterization of colonization-deficient mutants of Actinobacillus suis. Vet Microbiol $140,122-130$

Oliveira S. 2007. Update on Actinobacillus suis diagnosis, epidemiology, and control: On the path from good to great. American Association of Swine Veterinarians 38, 371-376.

Oliveira S, J Tomaszewski, J Collins. 2007. Actinobacillus suis molecular epidemiology. AAVLD Annual Conference Proceedings, Reno, Nevada, USA, 137.

Patterson-Kane JC, JM Donahue, LR Harrison. 2001. Septicemia and peritonitis due to Actinobacillus equuli infection in adult horse. Vet Pathol 38, 230-232.

Pedersen KB. 1977. Actinobacillus infections in swine. Nord Vet 29, 137-140.

Peel MM, KA Hornidge, M Luppino, AM Stacpoole, RE Weaver. 1991. Actinobacillus spp. and related bacteria in infected wounds of humans bitten by horses and sheep. J Clin Microbiol 29, 2535-2538.

Pusterla N, M Jones, F Mohor, J Higgins, S Mapes, S Jang. 2008. Fatal pulmonary hemorrhage associated with RTX toxin-producing Actinobacillus equuli subsp. haemolyticus infection in an adult horse. J Vet Diagn Invest 20, 118-121.

Ramos-Vara JA, CC Wu, I Mitsui, TL Lin, MA Miller. 2008. Metritis, valvular endocarditis, and septicemia by Actinobacillus equuli in a gilt in the United States. Vet Pathol 45, 495-499.

Robinson WF, MG Maxie. 1993. The cardiovascular system. In: Jubb KVF, Kennedy PC, Palmer N (eds). Pathology of domestic animals. $4^{\text {th }}$ ed. Academic Press, California, USA, Pp 24-27.

Rosendal S, KR Mittal. 1985. Serological cross-activity between a porcine Actinobacillus strain and Haemophilus pleuropneumoniae. Can J Comp Med 49, 164-170.

Ross RF, JE Hall, AP Orning, SE Dale. 1972. Characterization of an Actinobacillus isolated from the sow vagina. Int J Syst Bacteriol 22, 39-46.

Rullo A, E Papp-Szabo, FS Michael, JI MacInnes, MA Monteiro. 2006. The structural basis for the serospecificity of Actinobacillus suis serogroup O:2. Biochem Cell Biol 84, 184-190.

Rycroft AN, LH Garside. 2000. Actinobacillus species and their role in animal disease. Vet $J$ 159, 18-36.

Sanford SE, OP Miniats. 1988. Actinobacillus suis septicemia mimicking erysipelas in sows. Can Vet J 29, 595.

Sanford SE, GK Josephson, AJ Rehmtulla, AM Tilker. 1990. Actinobacillus suis infection in pigs in southwestern Ontario. Can Vet J 31, 443-447.

Sarli G, L Mandrioli, S Panarese, B Brunetti, J Segales, J Dominguez, PS Marcato. 2008. Characterization of interstitial nephritis in pigs with naturally occurring postweaning multisystemic wasting syndrome. Vet Pathol 45, 12-18.

Segales J, GM Allan, M Domingo. 2005. Porcine circovirus diseases Anim Health Res Rev 6, 119-142.

Slavic D, J DeLay, MA Hayes, JI MacInnes. 2000a. Comparative pathogenicity of different Actinobacillus suis O/K serotypes. Can J Vet Res 64, 81-87. 
Slavic D, TL Toffner, MA Monteiro, MB Perry, JI MacInnes. 2000 Prevalence of O1/K1 and O2/K3 reactive Actinobacillus suis in healthy and diseased swine. J Clin Microbiol 38, 3759-3762.

Sternberg S, B Brandstrom. 1999. Biochemical fingerprinting and ribotyping of isolates of Actinobacillus equuli from healthy and diseased horses. Vet Microbiol 66, 53-65.

Sulochana S, D Sudharma, ES Mathew, PT Georgekutty. 1985. A note on the isolation of Actinobacillus suis from a buffalo calf. In J Comp Microbiol Immun Inf Dis 6, 181-182.

Taylor DJ. 2006. Actinobacillus suis. In: Straw BE, Zimmerman JJ, D'Allaire S, Taylor DJ (eds). Diseases of Swine. $9^{\text {th }}$ ed. Blackwell Publishing, Ames, Iowa, USA, Pp 827-829.

Thibault S, R Drolet, MC Germain, S D'Allaire, R Larochelle, R Magar. 1998. Cutaneous and systemic necrotizing vasculitis in swine. Vet Pathol 35, 108-116.

Thompson AB, RC Postey, T Snider, T Pasma. 2010. Actinobacillus equuli as a primary pathogen in breeding sows and piglets. Can Vet J 51, 1223-1225.

Van Ostaaijen J, J Frey, S Rosendal, JI MacInnes. 1997. Actinobacillus suis strains isolated from healthy and diseased swine are clonal and carry apxICABD var.suis and apxIICA var.suis toxin genes. J Clin Microbiol 35, 1131-1137.

Vaz R, K Kennedy, G Shannon, M Peel. 2001. Septicemia in a horse trainer caused by Actinobacillus equuli. Clin Microbiol Newsletter 23, 151-153.
Webb RF, FA Cockram, L Pryde. 1976. The isolation of Actinobacillus equuli from equine abortion. Aust Vet J 52, 100-101.

Werdin RE, JP Hurtgen, FY Bates, FC Borgwardt. 1976. Porcine abortion caused by Actinobacillus equuli. J Am Vet Med Assoc 169, 704-706.

Wilson RJ, S McOrist. 2000. Actinobacillus suis infection in pigs in Australia. Aust Vet J 78, 317-319.

Windsor RS. 1973. Actinobacillus equuli infection in a litter of pigs and a review of previous reports on similar infections. Vet Rec 92, 178-180.

Woldehiwet Z. 2004. Actinobacillus suis abortion: a possible cause for concern in pigs. Vet $J 168,116-117$.

Wood RR, LM Henderson. 2006. Erysipelas. In: Straw BE, Zimmerman JJ, D'Allaire S, Taylor DJ (eds). Diseases of Swine. $9^{\text {th }}$ ed. Blackwell Publishing, Ames, Iowa, USA, Pp 629-638.

Xu M, S Wang, L Li, L Lei, Y Liu, W Shi, J Wu, L Li, F Rong, M Xu, G Sun, H Xiang, X Cai. 2010. Secondary infection with Streptococcus suis serotype 7 increases the virulence of highly pathogenic porcine reproductive and respiratory syndrome virus in pigs. Virol $J$ 7, 184.

Yaeger MJ. 1996. An outbreak of Actinobacillus suis septicemia in grow/ finish pigs. J Vet Diagn Invest 8, 381-383.

Zimmerman J, DA Benfield, MP Murtaugh, F Osorio, GM Stevenson, M Torremorell. 2006. Porcine reproductive and respiratory syndrome virus (Porcine arterivirus). In: Straw BE, Zimmerman JJ, D'Allaire S, Taylor DJ (eds). Diseases of swine. $9^{\text {th }}$ ed. Blackwell Publishing, Ames, Iowa, USA, Pp 387-417. 